\title{
Valparaiso University
} ValpoScholar

3-25-2010

\section{A Balloon Sounding Technique for Measuring SO2 Plumes}

\author{
Gary A. Morris \\ Valparaiso University \\ Walter D. Komhyr \\ EnSci Corporation \\ Jun Hirokawa \\ Hokkaido University \\ James Flynn \\ University of Houston - Main \\ Barry Lefer \\ University of Houston - Main \\ See next page for additional authors
}

Follow this and additional works at: http://scholar.valpo.edu/phys_astro_fac_pub

Part of the Atmospheric Sciences Commons

\section{Recommended Citation}

Morris, Gary A., Walter D. Komhyr, Jun Hirokawa, James Flynn, Barry Lefer, Nicholay Krotkov, Fong Ngan, 2010: A balloon sounding technique for measuring so2 plumes. J. Atmos. Oceanic Technol., 27, 1318-1330. doi: 10.1175/2010JTECHA1436.1

This Article is brought to you for free and open access by the Department of Physics and Astronomy at ValpoScholar. It has been accepted for inclusion in Physics and Astronomy Faculty Publications by an authorized administrator of ValpoScholar. For more information, please contact a ValpoScholar staff member at scholar@valpo.edu. 
Authors

Gary A. Morris, Walter D. Komhyr, Jun Hirokawa, James Flynn, Barry Lefer, Nicholay Krotokov, and Fong Ngan 


\title{
A Balloon Sounding Technique for Measuring $\mathrm{SO}_{2}$ Plumes
}

\author{
GARY A. MORRIS, ${ }^{*}$ WALTER D. KOMHYR, ${ }^{+}$JUn HiROKAWA, ${ }^{\#}$ JAMES FlynN, ${ }^{@}$ \\ BARRY LEFER, ${ }^{@}$ NICHOLAY KROTKOV, ${ }^{\&}$ AND FONG NGAN** \\ * Department of Physics and Astronomy, Valparaiso University, Valparaiso, Indiana \\ ${ }^{+}$EnSci Corporation, Boulder, Colorado \\ \# Faculty of Environmental Earth Science, Hokkaido University, Sapporo, Hokkaido, Japan \\ ${ }^{@}$ Department of Earth and Atmospheric Science, University of Houston, Houston, Texas \\ ${ }^{\&}$ GEST Center, University of Maryland, Baltimore County, Baltimore, Maryland \\ ** NOAA/Air Resources Laboratory, Silver Spring, Maryland
}

(Manuscript received 22 December 2009, in final form 25 March 2010)

\begin{abstract}
This paper reports on the development of a new technique for inexpensive measurements of $\mathrm{SO}_{2}$ profiles using a modified dual-ozonesonde instrument payload. The presence of $\mathrm{SO}_{2}$ interferes with the standard electrochemical cell (ECC) ozonesonde measurement, resulting in -1 molecule of $\mathrm{O}_{3}$ reported for each molecule of $\mathrm{SO}_{2}$ present (provided $\left[\mathrm{O}_{3}\right]>\left[\mathrm{SO}_{2}\right]$ ). In laboratory tests, an $\mathrm{SO}_{2}$ filter made with $\mathrm{CrO}_{3}$ placed on the inlet side of the sonde removes nearly $100 \%$ of the $\mathrm{SO}_{2}$ present for concentrations up to 60 ppbv and remained effective after exposure to $2.8 \times 10^{16}$ molecules of $\mathrm{SO}_{2}$ [equivalent to a column $\sim 150 \mathrm{DU}$ ( $1 \mathrm{DU}=$ $2.69 \times 10^{20}$ molecules $\mathrm{m}^{-2}$ )]. Flying two ECC instruments on the same payload with one filtered and the other unfiltered yields $\mathrm{SO}_{2}$ profiles, inferred by subtraction. Laboratory tests and field experience suggest an $\mathrm{SO}_{2}$ detection limit of $\sim 3 \mathrm{pbb}$ with profiles valid from the surface to the ozonopause [i.e., $\sim(8-10 \mathrm{~km})$ ]. Two example profiles demonstrate the success of this technique for both volcanic and industrial plumes.
\end{abstract}

\section{Introduction}

$\mathrm{SO}_{2}$ is a trace atmospheric constituent with a lifetime of 1-2 days in the lower troposphere (Krueger et al. 2000; Benkovitz et al. 2004) and is emitted both naturally by volcanoes and anthropogenically by certain power plant and industrial facilities. The earth's radiative budget is impacted when $\mathrm{SO}_{2}$ is converted to sulfate aerosols via reactions with $\mathrm{H}_{2} \mathrm{O}_{2}$ in clouds or $\mathrm{OH}$ (Seinfeld and Pandis 1998; Chin et al. 2000), although the extent of the influence of $\mathrm{SO}_{2}$ on climate and atmospheric chemistry remains uncertain. The Intergovernmental Panel on Climate Change (Soloman et al. 2007) reports sulfate aerosol direct radiative forcing of $-0.4 \pm 0.2 \mathrm{~W} \mathrm{~m}^{-2}$. Future implementation of pollution reduction policies, however, could lead to positive net forcings relative to today (Kloster et al. 2008).

Corresponding author address: Gary Morris, Dept. of Physics and Astronomy, Valparaiso University, 1610 Campus Dr. East, Valparaiso, IN 46383.

E-mail: gary.morris@valpo.edu
Retrieval techniques for the measurement of $\mathrm{SO}_{2}$ from satellite instruments were suggested by Krueger (1983) and refined by Krueger et al. (1995) and Krotkov et al. (1997). Because of its available wavelengths and spatial resolution ( $\sim 50 \mathrm{~km}$ at nadir and $\sim 100 \mathrm{~km}$ average), the Total Ozone Mapping Spectrometer (TOMS) $\mathrm{SO}_{2}$ retrievals were limited to large amounts in volcanic eruptions (Krueger et al. 1995, 2000; Carn et al. 2003) and exceptional pollution events (Carn et al. 2004). Greatly improved sensitivity was demonstrated through the detection of volcanic and anthropogenic $\mathrm{SO}_{2}$ in full-spectrum ultraviolet (UV) data provided by the Global Ozone Monitoring Experiment (GOME) (Eisinger and Burrows 1998; Burrows et al. 1999; Thomas et al. 2005; Khokhar et al. 2005) and the Scanning Imaging Absorption Spectrometer for Atmospheric Cartography (SCIAMACHY) (Bovensmann et al. 1999; Bramstedt et al. 2004; Richter et al. 2006; Lee et al. 2008). However, GOME needs 3 days and SCIAMACHY 6 days to acquire a contiguous global map and hence could miss short-lived pollution events. Recently, Kearney et al. (2008) have developed an $\mathrm{SO}_{2}$ retrieval for Moderate Resolution Imaging Spectroradiometer (MODIS) data. 
The Ozone Monitoring Instrument (OMI) (Levelt et al. 2006a,b) launched on the National Aeronautics and Space Administration (NASA) Aura satellite (Schoeberl et al. 2006) in July 2004 offers better spatial resolution (13 km $\times$ $24 \mathrm{~km}$ at nadir) and contiguous global daily coverage, permitting high-resolution, daily space-based UV measurements of $\mathrm{SO}_{2}$ (Krotkov et al. 2006, 2007; Yang et al. 2007, 2009a,b; Lee et al. 2009). Validation of these satellite observations has been limited to aircraft in situ measurements over the eastern United States (Taubman et al. 2006) and eastern China (Dickerson et al. 2007; Krotkov et al. 2008), ground-based remote sensing [e.g., the Brewer UV spectrometer network described in Fioletov et al. (1998) and Krueger et al. (1995)], and, most recently, with miniature differential optical absorption spectroscopy (mini-DOAS) instruments (Galle et al. 2010). However, these ground-based techniques provide little information on the vertical profile of $\mathrm{SO}_{2}$, an important factor in satellite column $\mathrm{SO}_{2}$ retrieval algorithms. To date, no inexpensive, regular in situ sampling program has been available to further these validation studies. The satellite community would find very valuable a sounding technique for in situ measurement of $\mathrm{SO}_{2}$ of similar cost to the standard ozonesonde.

To review, the standard ozonesonde, originally presented in Komhyr (1969), uses an iodine-iodide redox electrochemical cell (ECC) made of two platinum electrodes immersed in potassium iodide (KI) solutions in separate cathode $(0.5 \%-2 \%$ solution) and anode (saturated solution) polytetrafluoroethylene (Teflon) chambers (see Fig. 1). The chambers are linked by an ion bridge that allows for the exchange of charge but prevents mixing of the cathode and anode solutions. After charging the cells with the solutions, a transient potential difference results that is dissipated through the redistribution of charge across the ion bridge, such that the following equilibria are established:

$$
\begin{gathered}
3 \mathrm{I}^{-} \ddot{\mathrm{A}} \mathrm{I}_{3}^{-}+2 \mathrm{e}^{-} \text {(anode), } \\
2 \mathrm{I}^{-} \ddot{\mathrm{A}} \mathrm{I}_{2}+2 \mathrm{e}^{-} \text {(cathode). }
\end{gathered}
$$

When $\mathrm{O}_{3}$ bubbles through the cathode solution, a chemical reaction imbalances the cathode solution in favor of $\mathrm{I}_{2}$ :

$$
2 \mathrm{KI}+\mathrm{O}_{3}+\mathrm{H}_{2} \mathrm{O} \rightarrow 2 \mathrm{KOH}+\mathrm{I}_{2}+\mathrm{O}_{2} .
$$

To rebalance the cell, electrons must flow from the anode across the ion bridge to the cathode so that

$$
\begin{gathered}
\left.3 \mathrm{I}^{-} \rightarrow \mathrm{I}_{3}^{-}+2 \mathrm{e}^{-} \text {(anode }\right), \\
\mathrm{I}_{2}+2 \mathrm{e}^{-} \rightarrow 2 \mathrm{I}^{-}(\text {cathode }) .
\end{gathered}
$$

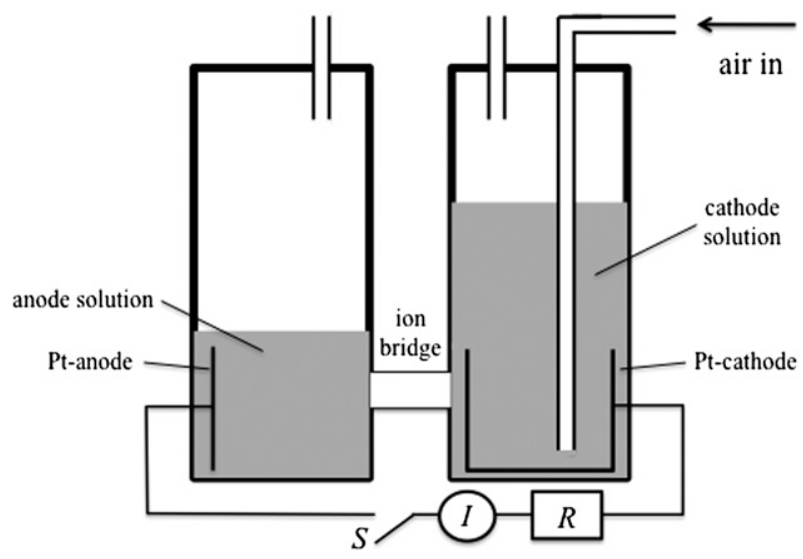

FIG. 1. A schematic of the ECC sonde cathode and anode chambers, connected by an ion bridge and an external ammeter to measure the current between the cells, which is proportional to the $\mathrm{O}_{3}$ concentration in the ambient air around the sonde.

If $\mathrm{SO}_{2}$ is present, however, the cathode chamber chemistry is altered:

$$
\mathrm{SO}_{2}+2 \mathrm{H}_{2} \mathrm{O} \rightarrow \mathrm{SO}_{4}^{2-}+4 \mathrm{H}^{+}+2 \mathrm{e}^{-} .
$$

In the presence of both $\mathrm{O}_{3}$ and $\mathrm{SO}_{2}$, therefore, reaction (1.6), rather than the anode solution reaction (1.4), supplies the electrons needed to rebalance the ECC after reaction (1.3). The result is that in the presence of both species with $\left[\mathrm{SO}_{2}\right]<\left[\mathrm{O}_{3}\right]$, the standard ozonesonde actually reports $\left[\mathrm{O}_{3}\right]-\left[\mathrm{SO}_{2}\right]$.

One approach to measure $\mathrm{SO}_{2}$ directly, therefore, is to filter the incoming air to remove $\mathrm{O}_{3}$ and electrically bias the cathode cell. When $\mathrm{SO}_{2}$ enters, reaction (1.6) results in a flow of electrons from the cathode cell across the ion bridge to the anode. Figure 2 shows data previously unpublished from a flight in Pittsburg, Pennsylvania, on 24 February 1983 that used this approach. The figure shows a low-altitude peak of $\sim 35 \mathrm{ppbv}$ of $\mathrm{SO}_{2}$ just above the mixed layer, with a broader $\mathrm{SO}_{2}$ peak of $\sim 65-$ 72 ppbv trapped between two temperature inversions at $\sim 0.7$ and $1.7 \mathrm{~km}$. Such high levels of $\mathrm{SO}_{2}$ are not observed in modern data, as U.S. emissions decreased by $\sim 37 \%$ from the 1970 to 1996 (EPA 2000).

A second approach is to fly two instruments side-byside, one with a filter to remove $\mathrm{SO}_{2}$ and the other without, as shown in Fig. 3. Since the filtered sonde will measure $\left[\mathrm{O}_{3}\right.$ and the unfiltered sonde will measure $\left[\mathrm{O}_{3}\right]$ - $\left[\mathrm{SO}_{2}\right]$, the concentration of $\left[\mathrm{SO}_{2}\right]$ can be derived by subtraction. The technique relies upon finding a filter that effectively removes $\mathrm{SO}_{2}$ without impacting the $\mathrm{O}_{3}$ concentrations.

In this paper we describe the development of such a technique using a modified dual-ozonesonde payload. 


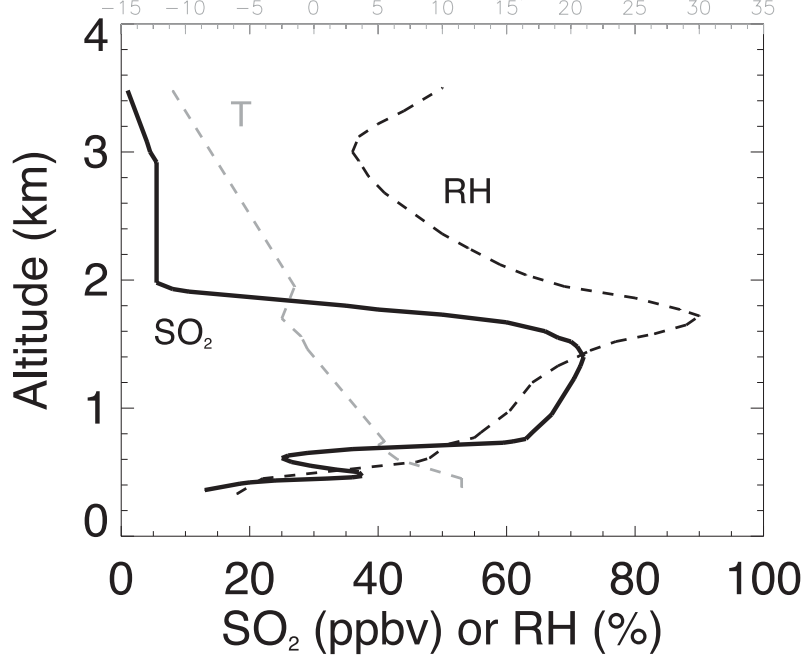

FIG. 2. The first sounding of $\mathrm{SO}_{2}$ with temperature and relative humidity profiles made by W. Komhyr in Pittsburg, PA, on 24 Feb 1983.

Laboratory tests demonstrate the effectiveness of the technique for measuring tropospheric $\mathrm{SO}_{2}$ profiles for $\sim 3$ ppbv $<\left[\mathrm{SO}_{2}\right]<\left[\mathrm{O}_{3}\right]$. Two examples from field deployments demonstrate the effectiveness and utility of the technique: 1) volcanic emissions observed over Sapporo, Japan; and 2) industrial emissions observed over Houston, Texas. Since the filtered sonde and unfiltered sonde share the same balloon, parachute, payout-reel, and GPS and radiosonde units, the cost of a balloon flight with the dual payload is only about $40 \%$ higher than the cost of a standard ozonesonde.

\section{Laboratory tests}

We conducted a number of controlled laboratory tests during the development of our $\mathrm{SO}_{2}$ sounding technique. The appendix describes tests performed on the various components used in the construction of the $\mathrm{SO}_{2}$ filter, as well as the results of possible alternate $\mathrm{SO}_{2}$ filter solutions. For all tests and flights, we use $0.5 \%$ buffered KI solutions in the cathode cell and saturated KI solutions in the anode cell (solutions prepared by B. Johnson, NOAA/Climate Monitoring and Diagnostics Laboratory, 2008-2009, personal communication), as recommended by the Jülich Ozone Sonde Intercomparison Experiment (JOSIE) (Smit et al. 2007).

The EnSci $\mathrm{SO}_{2}$ filter consists of a Teflon cell $(\sim 5 \mathrm{cc})$ containing treated filter paper cut into $\sim 3 \mathrm{~mm} \times \sim 12 \mathrm{~mm}$ strips. The original filters used glass filter paper (2008 data; see the appendix), while the new filters use Teflon paper (2009 data, below). A 15-ml aqueous solution with $2.5 \mathrm{~g}$ of $\mathrm{CrO}_{3}$ and $0.7 \mathrm{ml}$ concentrated $\mathrm{H}_{2} \mathrm{SO}_{4}$ is used to

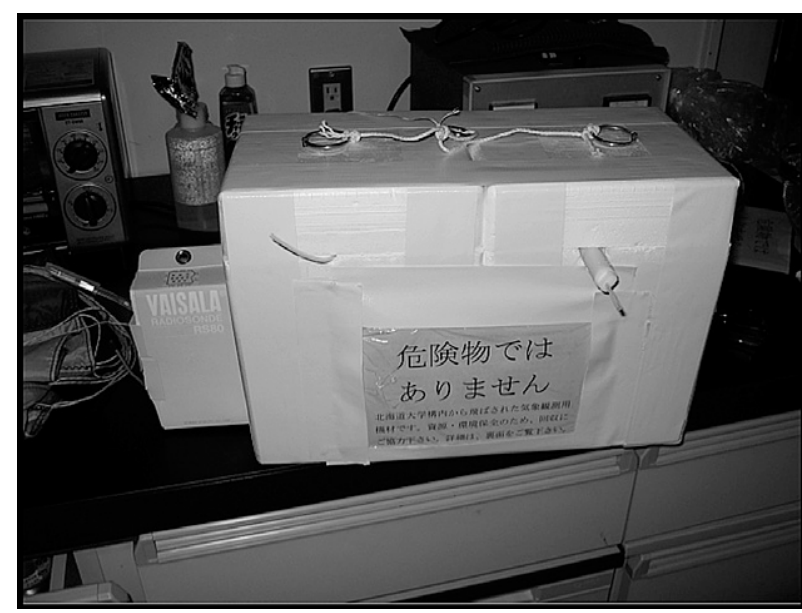

FIG. 3. The dual $\mathrm{O}_{3}-\mathrm{SO}_{2}$ sonde payload. From left to right are the Väisälä RS80-15N radiosonde, the unfiltered ECC ozonesonde, and the $\mathrm{SO}_{2}$ filtered ECC ozonesonde using the EnSci $\mathrm{CrO}_{3}$ filter.

treat $\sim 400 \mathrm{~cm}^{2}$ of filter paper. The paper is then dried in an oven at $80^{\circ}-90^{\circ} \mathrm{C}$ for $1 \mathrm{~h}$. Each strip is folded in half and inserted into the Teflon cell. Before use, it is recommended that the filter be exposed to high ozone in dry air for several hours. If the filter paper becomes damp, drying in an $80^{\circ} \mathrm{C}$ oven followed by high-ozone conditioning is recommended. The original suggestion for use of such a $\mathrm{CrO}_{3}$ filter to remove $\mathrm{SO}_{2}$ from sample air can be found in Saltzman and Wartburg (1965), while use of such a filter in surface $\mathrm{SO}_{2}$ measurements is described in Warmbt and Herrmann (1977).

Laboratory tests on this filter demonstrated its effectiveness. The University of Houston (UH) test consisted of a Thermo Electron Corporation (TECO) 49C-PS ozone calibrator, a TECO $146 \mathrm{C}$ multigas calibrator (used to control the $\mathrm{SO}_{2}$ concentrations), a manifold for mixing and distributing the gasses, a TECO Model 49C ozone analyzer using the U.S. Environmental Protection Agency standard measurement technique (EQOA0880-047), a modified TECO 43S SO2 analyzer (Luke 1997), an unfiltered ozonesonde, and a filtered ozonesonde. The experimental setup is shown in Fig. 4.

Tests were performed with $\mathrm{O}_{3}$ concentrations of approximately 120,80 , and $40 \mathrm{ppbv}$ (in that order) and $\mathrm{SO}_{2}$ concentrations ranging from $\sim(2.5-65) \mathrm{ppbv}$. The data are shown in Tables 1-3. Each paired combination of $\mathrm{O}_{3}$ and $\mathrm{SO}_{2}$ was maintained for 3-5 min. An overall background level was established through data taken at $\left[\mathrm{O}_{3}\right]=0$ and $\left[\mathrm{SO}_{2}\right]=0$, and at each $\mathrm{O}_{3}$ level, additional backgrounds are established with $\left[\mathrm{SO}_{2}\right]=0$. None of the data in Tables 1-3, however, have been adjusted for the background levels.

Within the 120- and 80-ppbv levels, the performance of the filter as a function of the integrated exposure to 


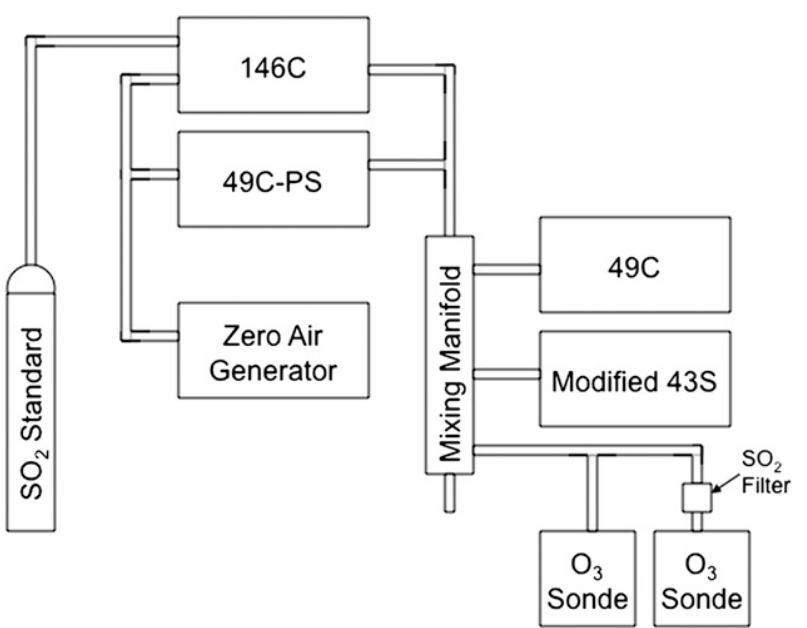

FIG. 4. A schematic of the instruments used in the laboratory test of the EnSci $\mathrm{CrO}_{3}$ version of the $\mathrm{SO}_{2}$ filter conducted at the University of Houston in July 2009.

$\mathrm{SO}_{2}$ changes very little. A linear regression analysis of the difference between the dual-sonde-derived and TECO-measured $\mathrm{SO}_{2}$ concentrations as a function of integrated $\mathrm{SO}_{2}$ exposure shows slopes of $0.005 \pm$ 0.011 ppbv per Dobson unit $(\mathrm{DU} ; 1 \mathrm{DU}=2.69 \times$ $10^{20}$ molecules $\mathrm{m}^{-2}$ ) and $-0.0078 \pm 0.0081 \mathrm{ppbv} \mathrm{DU}^{-1}$, respectively. Between the two tests, an offset of $\sim 1 \mathrm{ppbv}$ of $\mathrm{SO}_{2}$ is observed, as seen in the data in Tables 1 and 2.

Integrating the $\mathrm{SO}_{2}$ concentrations passed through the filter as a function of time through the first two of the three $\mathrm{O}_{3}$ levels in our test, we find a cumulative exposure of $\sim 2.8 \times 10^{16}$ molecules of $\mathrm{SO}_{2}$. We can compute an equivalent column of $\mathrm{SO}_{2}$ in flight from the equation

$$
\text { Column } \mathrm{SO}_{2}(\mathrm{DU})=\frac{N \dot{z}}{\dot{V}}
$$

where $N$ is the total number of molecules passed through the filter in the test, $\dot{u}$ is the rise rate of the balloon in flight $\left(5 \mathrm{~m} \mathrm{~s}^{-1}\right)$, and $\dot{V}$ is the pump volume flow rate

TABLE 1. Individual readings for the $\sim 120 \mathrm{ppbv}$ ozone test. The mean ozone difference (sonde - TECO) $=0.3 \pm 4.8 \mathrm{ppbv}$, while the mean $\mathrm{SO}_{2}$ difference (sonde $-\mathrm{TECO}$ ) $=-0.87 \pm 2.3 \mathrm{ppbv}$.

\begin{tabular}{cccr}
\hline $\begin{array}{c}\mathrm{TECO} \mathrm{O}_{3} \\
(\mathrm{ppbv})\end{array}$ & $\begin{array}{c}\text { Sonde } \mathrm{O}_{3} \\
(\mathrm{ppbv})\end{array}$ & $\begin{array}{c}\mathrm{TECO} \mathrm{SO} \\
(\text { ppbv })\end{array}$ & \multicolumn{1}{c}{$\begin{array}{c}\text { Sonde } \mathrm{SO}_{2} \\
(\text { ppbv })\end{array}$} \\
\hline $121.64 \pm 0.97$ & $118.32 \pm 0.50$ & $-0.034 \pm 0.082$ & $0.49 \pm 0.68$ \\
$120.6 \pm 1.2$ & $120.27 \pm 0.90$ & $65.35 \pm 0.64$ & $66.12 \pm 0.64$ \\
$120.76 \pm 0.69$ & $121.13 \pm 0.40$ & $46.90 \pm 0.49$ & $48.10 \pm 0.51$ \\
$121.27 \pm 0.71$ & $121.48 \pm 0.64$ & $27.81 \pm 0.51$ & $28.54 \pm 0.65$ \\
$121.78 \pm 0.68$ & $122.57 \pm 0.52$ & $18.04 \pm 0.33$ & $18.92 \pm 0.61$ \\
$119.97 \pm 0.84$ & $122.3 \pm 1.9$ & $9.03 \pm 0.28$ & $10.13 \pm 0.64$ \\
$121.5 \pm 1.9$ & $122.9 \pm 1.7$ & $3.90 \pm 0.27$ & $5.03 \pm 0.55$ \\
$122.9 \pm 1.3$ & $123.9 \pm 1.3$ & $0.03 \pm 0.16$ & $0.77 \pm 0.72$ \\
\hline
\end{tabular}

TABLE 2. Individual readings for the $\sim 80 \mathrm{ppbv}$ ozone test. The mean ozone difference (sonde $-\mathrm{TECO})=1.2 \pm 8.0 \mathrm{ppbv}$, while the mean $\mathrm{SO}_{2}$ difference (sonde - TECO) $=-1.2 \pm 1.9 \mathrm{ppbv}$

\begin{tabular}{cccr}
\hline \hline $\begin{array}{c}\mathrm{TECO} \mathrm{O}_{3} \\
\text { (ppbv) }\end{array}$ & $\begin{array}{c}\text { Sonde } \mathrm{O}_{3} \\
(\text { ppbv) }\end{array}$ & $\begin{array}{c}\mathrm{TECO} \mathrm{SO}_{2} \\
(\mathrm{ppbv})\end{array}$ & \multicolumn{1}{c}{$\begin{array}{c}\text { Sonde } \mathrm{SO}_{2} \\
(\text { ppbv })\end{array}$} \\
\hline $81.0 \pm 2.1$ & $82.7 \pm 1.9$ & $-0.009 \pm 0.090$ & $-0.98 \pm 0.70$ \\
$82.0 \pm 2.8$ & $84.1 \pm 2.7$ & $65.85 \pm 0.49$ & $65.12 \pm 0.68$ \\
$80.4 \pm 2.0$ & $81.5 \pm 1.6$ & $47.20 \pm 0.46$ & $46.38 \pm 0.55$ \\
$80.8 \pm 1.4$ & $81.56 \pm 0.92$ & $27.85 \pm 0.36$ & $26.43 \pm 0.34$ \\
$79.9 \pm 2.6$ & $81.3 \pm 2.0$ & $18.85 \pm 0.38$ & $17.36 \pm 0.51$ \\
$80.7 \pm 1.3$ & $81.7 \pm 1.0$ & $9.05 \pm 0.29$ & $7.60 \pm 0.56$ \\
$81.7 \pm 2.1$ & $82.5 \pm 1.5$ & $3.95 \pm 0.24$ & $2.45 \pm 0.51$ \\
$80.1 \pm 2.6$ & $80.9 \pm 2.2$ & $0.02 \pm 0.12$ & $-1.24 \pm 0.55$ \\
\hline
\end{tabular}

$\left(3.45 \mathrm{cc} \mathrm{s}^{-1}\right)$. Thus the laboratory test was equivalent to an $\mathrm{SO}_{2}$ column of $\sim 150$ DU. Even after such exposure, the filter performance was still quite good. For the 40-ppbv-level test, we used a new $\mathrm{SO}_{2}$ filter of the same type as for the 120- and 80-ppbv tests. The same linear regression analysis as above reveals a slope of $0.0458 \pm$ 0.0083 ppbv $\mathrm{DU}^{-1}$ exposure, with most of the change occurring over the last four levels of data [i.e., when $\mathrm{SO}_{2}$ was lowered from $\sim(20-2.5)$ ppbv]. While our dualsonde $\mathrm{SO}_{2}$ measurement changed more with respect to the TECO SO $\mathrm{S}_{2}$ measurement for this test than the previous two tests, the changes are still $<2 \mathrm{ppbv}$ of $\mathrm{SO}_{2}$ at a cumulative exposure of the equivalent of nearly 40 DU. Thus, the filters stand up well to high $\mathrm{SO}_{2}$ concentrations for extended periods of time, consistent with the findings of Saltzman and Wartburg (1965).

Figure 5 shows the filtered ozonesonde reading as a function of the TECO $\mathrm{O}_{3}$ reading. The regression of the overall data shows a line of best fit with a slope to within $1 \%$ of 1.00 and an intercept of less than one-half of one standard deviation from 0.00 . Good agreement is seen at all levels: at the 120-ppbv $\mathrm{O}_{3}$ level, the mean $\mathrm{O}_{3}$ difference (sonde $-\mathrm{TECO})=0.3 \pm 4.8 \mathrm{ppbv}$, while the mean $\mathrm{SO}_{2}$ difference (sonde $\left.-\mathrm{TECO}\right)=-0.87 \pm 2.3$ ppbv; at the 80-ppbv $\mathrm{O}_{3}$ level, the mean $\mathrm{O}_{3}$ difference

TABLE 3. Individual readings for the $\sim 40$ ppbv ozone test. The mean ozone difference (sonde - TECO) $=-1.0 \pm 5.3$ ppbv, while the mean $\mathrm{SO}_{2}$ difference (sonde $\left.-\mathrm{TECO}\right)=-0.74 \pm 1.5 \mathrm{ppbv}$.

\begin{tabular}{cccr}
\hline $\begin{array}{c}\mathrm{TECO} \mathrm{O}_{3} \\
\text { (ppbv) }\end{array}$ & $\begin{array}{c}\text { Sonde } \mathrm{O}_{3} \\
\text { (ppbv) }\end{array}$ & $\begin{array}{c}\mathrm{TECO} \mathrm{SO}_{2} \\
\text { (ppbv) }\end{array}$ & \multicolumn{1}{c}{$\begin{array}{c}\text { Sonde } \mathrm{SO}_{2} \\
\text { (ppbv) }\end{array}$} \\
\hline $40.9 \pm 1.8$ & $40.6 \pm 1.7$ & $-0.020 \pm 0.080$ & $-1.20 \pm 0.18$ \\
$40.4 \pm 1.0$ & $39.44 \pm 0.83$ & $34.71 \pm 0.35$ & $32.84 \pm 0.28$ \\
$41.2 \pm 1.3$ & $40.1 \pm 1.1$ & $32.95 \pm 0.41$ & $31.68 \pm 0.54$ \\
$39.5 \pm 1.9$ & $38.7 \pm 1.8$ & $27.92 \pm 0.34$ & $26.63 \pm 0.26$ \\
$42.4 \pm 1.4$ & $41.0 \pm 1.3$ & $18.13 \pm 0.49$ & $17.57 \pm 0.24$ \\
$42.2 \pm 1.5$ & $40.8 \pm 1.2$ & $9.07 \pm 0.30$ & $8.95 \pm 0.20$ \\
$38.6 \pm 1.3$ & $37.6 \pm 1.0$ & $2.48 \pm 0.16$ & $2.56 \pm 0.21$ \\
$43.84 \pm 0.66$ & $42.68 \pm 0.66$ & $0.03 \pm 0.12$ & $0.61 \pm 0.16$ \\
\hline
\end{tabular}




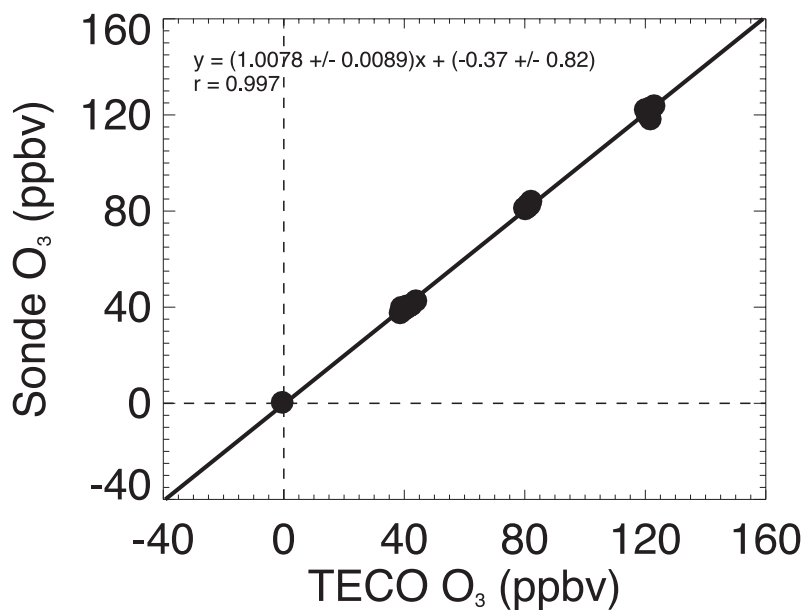

FIG. 5. The EnSci $\mathrm{CrO}_{3}$ version of the $\mathrm{SO}_{2}$ filter was tested at the University of Houston at three different $\mathrm{O}_{3}$ concentrations. Within each $\mathrm{O}_{3}$ concentration, $\mathrm{SO}_{2}$ was varied from 0 to $65 \mathrm{ppbv}$. Shown here is the $\mathrm{O}_{3}$ reported by the filtered sonde vs that measured by the standard TECO $\mathrm{O}_{3}$ analyzer. The response is linear, with reasonably high accuracy and precision. See text for details.

(sonde $-\mathrm{TECO})=1.2 \pm 8.0 \mathrm{ppbv}$, while the mean $\mathrm{SO}_{2}$ difference (sonde - TECO) $=-1.2 \pm 1.9$ ppbv; and at the 40-ppbv $\mathrm{O}_{3}$ level, the mean $\mathrm{O}_{3}$ difference (sonde TECO) $=-1.0 \pm 5.3$ ppbv, while the mean $\mathrm{SO}_{2}$ difference $($ sonde $-\mathrm{TECO})=-0.74 \pm 1.5 \mathrm{ppbv}$. We note that the uncertainties in the (sonde - TECO) $\mathrm{O}_{3}$ are rather large, owing to the fact that the $\mathrm{O}_{3}$ calibrator instrument experienced difficulty in maintaining $\mathrm{O}_{3}$ at constant concentrations. While we have not made adjustments for the offsets at $\left[\mathrm{SO}_{2}\right]=0$ for this test, we correct these offsets for flight data. The offsets can be corrected by adjustments in the background cell current of each ECC independently or through a subtraction from the postflight $\mathrm{SO}_{2}$ concentrations.

Figure 6 shows the derived $\mathrm{SO}_{2}$ concentration (filteredunfiltered) as a function of the TECO $\mathrm{SO}_{2}$ reading. Again, the regression of the entire dataset shows a line-of-best-fit slope to within $0.1 \%$ of 1.00 and an intercept of $-0.36 \pm$ 0.14 ppbv. The $\sim 40$ ppbv ozone level test was used to examine closely the limits of the $\mathrm{SO}_{2}$ measurement (data in Table 3). It appears that this technique can distinguish $2.5 \mathrm{ppbv}$ from $0 \mathrm{ppbv}$ of $\mathrm{SO}_{2}$ at the surface. In flight, the detection limit may be somewhat higher $[\sim(3-5)$ ppbv] due to differing response time constants of the two ECC instruments.

One final laboratory test at Hokkaido University examined the $\mathrm{SO}_{2}$ destruction properties of our 4-yr-old filters and used the experimental setup depicted in Fig. 7. The laboratory equipment consisted of a temperaturecontrolled oven for $\mathrm{SO}_{2}$ production and a chemical ionization mass spectrometer (CIMS) for measurement

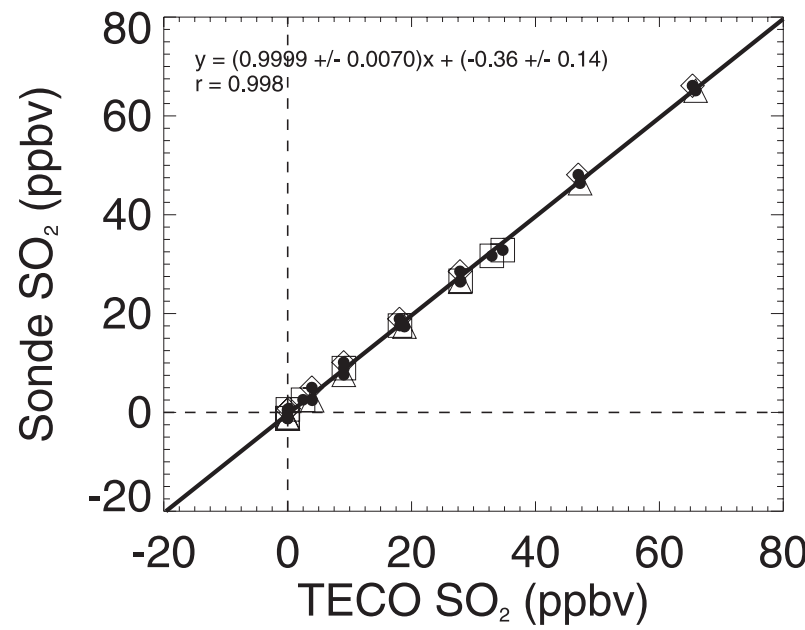

FIG. 6. As in Fig. 5, but here we examine the $\mathrm{SO}_{2}$ measurements. The dual-sonde response is quite linear, accurately reproducing the measurements made by the standard TECO $\mathrm{SO}_{2}$ analyzer. See text for details.

of the $\mathrm{SO}_{2}$ concentration. The details of the CIMS instrument are described in Hirokawa et al. (2009). $\mathrm{SO}_{2}$ gas was released at a rate of $120 \mathrm{ng} \mathrm{min}^{-1}$ from a permeation tube in the oven controlled at $40^{\circ} \mathrm{C}$ and was diluted by $\mathrm{N}_{2}$ at a flow rate of $200 \mathrm{~cm}^{3} \mathrm{~min}^{-1}$ to prepare a test gas mixture containing approximately $200 \mathrm{ppbv}$ of $\mathrm{SO}_{2}$. The test gas mixture was sampled in the glass inlet of the CIMS instrument both with and without passing through an $\mathrm{SO}_{2}$ filter. In the inlet, the $\mathrm{SO}_{2}-\mathrm{N}_{2}$ was further diluted by $\mathrm{N}_{2}$ at a flow rate of $1000 \mathrm{~cm}^{3} \mathrm{~min}^{-1}$ and then introduced into a chemical ionization region, in which $\mathrm{SO}_{2}$ was ionized via the following ion-molecule reactions (Huey et al. 1995; Lovejoy and Wilson 1998):

$$
\begin{aligned}
\mathrm{SF}_{6}^{-}+\mathrm{SO}_{2} & \rightarrow \mathrm{SO}_{2} \mathrm{~F}^{-}+\mathrm{SF}_{5} \\
& \rightarrow \mathrm{SO}_{2} \mathrm{~F}_{2}^{-}+\mathrm{SF}_{4}, \\
& \rightarrow \mathrm{SF}_{5}^{-}+\mathrm{SO}_{2} \mathrm{~F}
\end{aligned}
$$

The ions as well as the unreacted $\mathrm{SF}_{6}^{-}$were mass-analyzed by a quadrupole mass filter and detected by a secondary electron multiplier. The $\mathrm{SO}_{2}$ concentration was measured by monitoring ion signals of $\mathrm{SO}_{2} \mathrm{~F}_{2}^{-}$detected at a mass-tocharge ratio $(\mathrm{m} / \mathrm{z})$ of 102 .

Figure 8 shows the results of this test. The performance of two other tested filters, described in the appendix, is also shown in this figure. Despite their age, the $\mathrm{CrO}_{3}$ filters resulted in an $(87 \pm 14) \%$ reduction of $\mathrm{SO}_{2}$ at $\sim 200$ ppbv. We do not expect to encounter such high $\mathrm{SO}_{2}$ levels during our flights, and tests described above (made with Teflon filter paper in 2009) suggest that these new filters are nearly $100 \%$ effective at removing $\mathrm{SO}_{2}$. 


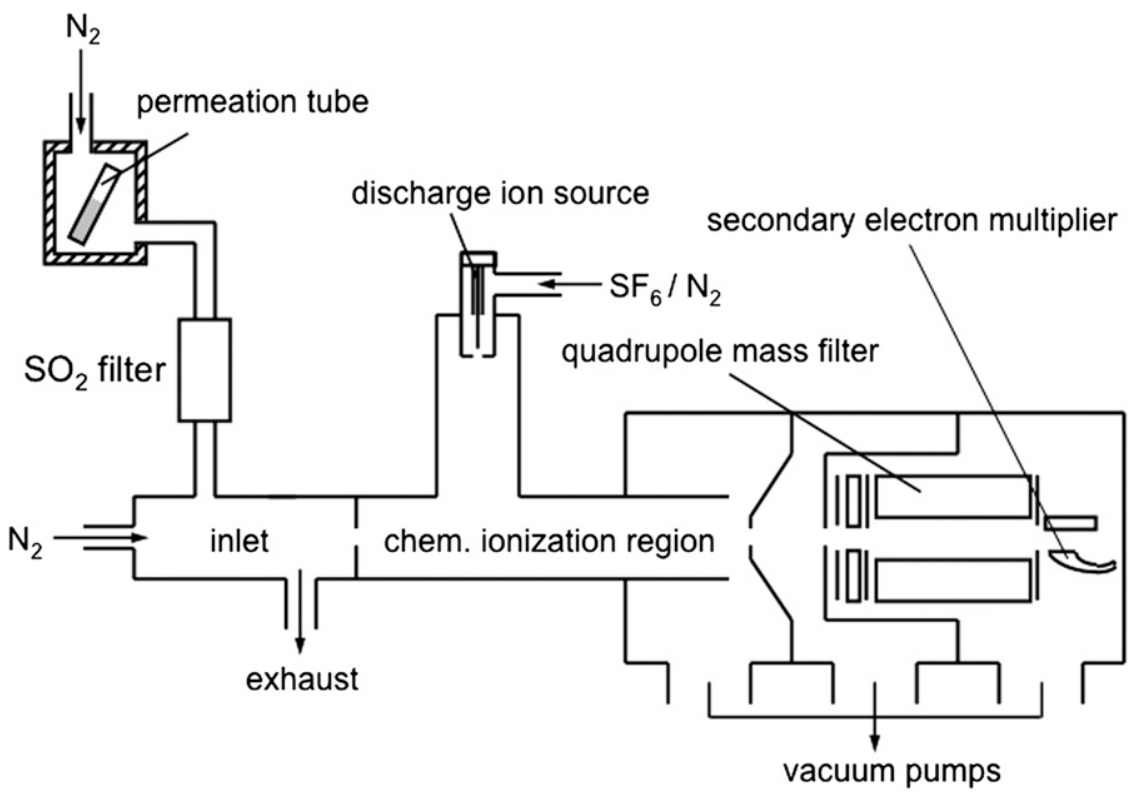

FIG. 7. A schematic of the instruments used in the laboratory test of the several different $\mathrm{SO}_{2}$ filters conducted at Hokkaido University in August 2008.

\section{Field observations}

\section{a. Ozonesonde background}

The example data presented here used the ECC type EnSci 2Z ozonesonde instruments (Komhyr 1986; Komhyr et al. 1995) with $0.5 \%$ buffered KI cathode solution. Meteorological measurements (pressure, temperature, and relative humidity) for all dual-sonde flights are provided by Väisälä RS80-15N radiosondes, as described in Thompson et al. (2003, 2007). Onboard global positioning systems (GPS) provided latitude, longitude, altitude, wind speed, and wind direction data. With a typical rise rate of $\sim 5 \mathrm{~m} \mathrm{~s}^{-1}$ and a measurement time constant of $\sim 25 \mathrm{~s}$, the effective vertical resolution of $\mathrm{O}_{3}$ features is $\sim 125 \mathrm{~m}$ (see also Smit et al. 2007).

Dual-ozonesonde payloads (Fig. 3) consisted of two such ECC cells, one with the EnSci $\mathrm{SO}_{2}$ filter on the inlet side and one without, so that, by subtraction, an $\mathrm{SO}_{2}$ profile was derived. (Note that the circuits of the two sondes have been modified by EnSci so that the data from the two instruments are combined and transmitted to the surface in the same datastream.) Differences in the measurement time constants between the two ECC units can result in the appearance of false $\mathrm{SO}_{2}$ signals as the sonde moves through air with strong vertical gradients in $\mathrm{O}_{3}$. Thus, evaluation of $\mathrm{SO}_{2}$ profiles requires some care. Nevertheless, we have had good success in producing tropospheric $\mathrm{O}_{3}$ and $\mathrm{SO}_{2}$ profiles on $20+$ dual-sonde payload balloon flights. (All of our data are available on our project Web sites: http://physics.valpo.edu/ozone, www.rice.edu/ ozone, and www.imaqs.uh.edu/ozone.)
Before each flight, the dual $\mathrm{O}_{3}-\mathrm{SO}_{2}$ payloads are bench tested to make sure the $\mathrm{SO}_{2}$ filter is properly conditioned and does not destroy $\mathrm{O}_{3}$. Inlets from the filtered and unfiltered sonde are connected to the EnSci ozonizer unit, which is set to 0 , low (10-40 ppbv), medium (40-80 ppbv), and high (80-300 ppbv) concentrations of $\mathrm{O}_{3}$. Figure 9 shows that for the 14 flights from Sapporo in August 2008 and 2009, the $\mathrm{O}_{3}$ readings reported by the two instruments agree extremely well, indicating that the filter is properly conditioned. The mean offset (secondary-primary) was $-0.4 \pm 2.3 \mathrm{ppbv}$, with a mean absolute offset (secondary-primary) of $1.5 \pm 1.8 \mathrm{ppbv}$.

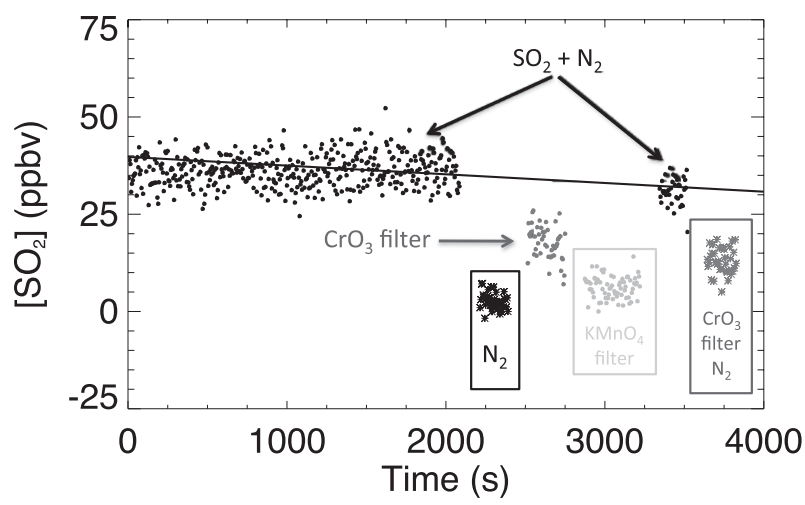

FIG. 8. Results of a laboratory test of different $\mathrm{SO}_{2}$ filters conducted at Hokkaido University in August 2008. The 4-yr-old EnSci $\mathrm{CrO}_{3}$ version of the filter removed $\sim 85 \%$ of the incident $\mathrm{SO}_{2}$, while the $\mathrm{KMnO}_{4}$ filter removed nearly $100 \%$. However, after high ozone conditioning, the $\mathrm{KMnO}_{4}$ filter no longer removed $\mathrm{SO}_{2}$. See text for details. 


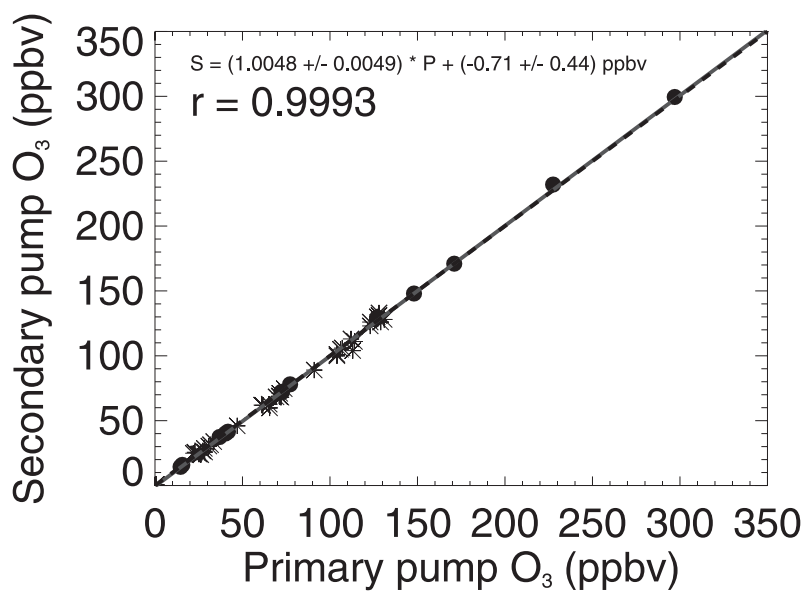

FIG. 9. Preflight comparison of $\mathrm{O}_{3}$ readings from the filtered and unfiltered ozonesondes conducted on the laboratory bench at 0 , low (0-40 ppbv), medium (40-80 ppbv), and high ( $>80$ ppbv) $\mathrm{O}_{3}$ concentrations, with good agreement shown. Data shown are from 4 dual $\mathrm{O}_{3}-\mathrm{SO}_{2}$ sonde flights from Hokkaido University in August 2008 (dots) and 10 flights in August 2009 (stars).

Such results suggest that the technique may be able to identify $\mathrm{SO}_{2}$ features of as little as 3 ppbv. This test should be performed before all dual $\mathrm{O}_{3}-\mathrm{SO}_{2}$ flights.

\section{b. Volcanic plume case-Sapporo, 22 August 2008}

At 0424 UTC 22 August 2008, we released a dual sonde from the campus of Hokkaido University in Sapporo $\left(43.07^{\circ} \mathrm{N}, 141.35^{\circ} \mathrm{E}\right.$; elevation $\left.26 \mathrm{~m}\right)$. Figure 10 shows the $\mathrm{SO}_{2}$ profile for this flight, with a prominent feature of $\sim 17$ ppbv between 0.45 and $0.95 \mathrm{~km}$. Since this flight employed a 4-yr-old $\mathrm{SO}_{2}$ filter, a correction factor was employed (this filter was determined to be $\sim 65 \%$ effective). Newer filters do not require such corrections since they are nearly $100 \%$ effective (see above).

Figure 10 also shows that relative humidity (RH) increases steadily from the surface $(\sim 38 \%)$ to $\sim 1.85 \mathrm{~km}$ $(87 \%)$, with values $\sim 50 \%$ in the layer of elevated $\mathrm{SO}_{2}$. Potential temperature (theta) is nearly constant at $295 \mathrm{~K}$ from the surface to $1.9 \mathrm{~km}$, where the temperature data indicate a strong inversion (not shown). Ozone is nearly constant at $\sim 40 \mathrm{ppbv}$ from the surface to $\sim 2.4 \mathrm{~km}$. Elevated $\mathrm{SO}_{2}$ is also seen up to $\sim 3 \mathrm{~km}$, but at much lower concentrations. If we integrate the $\mathrm{SO}_{2}$ column from the surface to $3 \mathrm{~km}$, we find $0.9 \mathrm{DU}$.

Figure 11 shows the $\mathrm{OMI} \mathrm{SO}_{2}$ map near Hokkaido for 0345-0349 UTC 22 August 2008, with a retrieval assuming a 3-km center for the peak height of the $\mathrm{SO}_{2}$ cloud. The OMI data show a swath of elevated $\mathrm{SO}_{2}$ $(>2.5 \mathrm{DU})$ stretching from eastern Siberia across the Tatar Strait to the northeast coast of Hokkaido, then southward into the Pacific, with values $\sim(0.3-1.0)$ DU

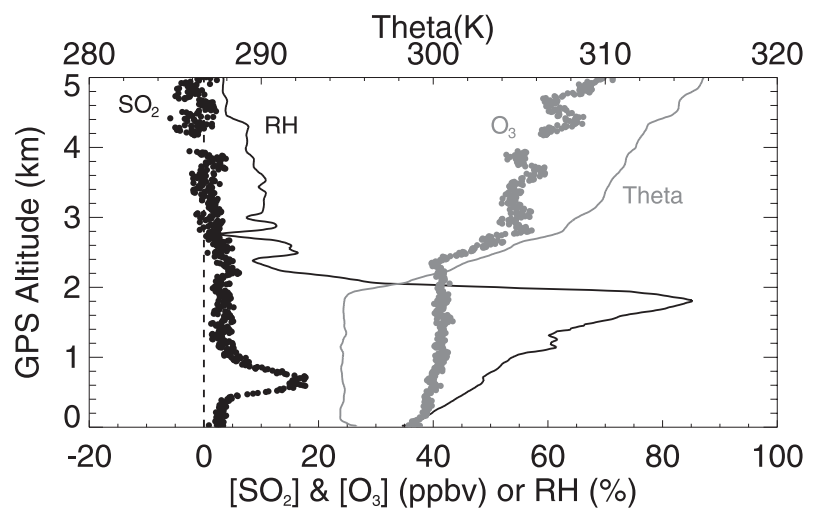

FIG. 10. Profiles of $\mathrm{SO}_{2}$ (black dots), $\mathrm{O}_{3}$ (gray dots), $\mathrm{RH}$ (black line), and theta (gray line) from the 22 Aug 2008 dual-sonde released from Hokkaido University in Sapporo, Japan. The $\mathrm{SO}_{2}$ peak near $0.7 \mathrm{~km}$ is most likely a plume from a volcanic eruption that has been transported to Hokkaido. See text for further details.

along the flight path of the dual sonde (due southeast of Sapporo).

There are two possible volcanic sources for the $\mathrm{SO}_{2}$ plume. Mt. Kasatochi erupted violently three times during 2200 UTC 7 August to 0435 UTC 8 August 2008, sending emissions to $>13.5 \mathrm{~km}$. Eruptions continued through $\sim 1800$ UTC 9 August. Emissions from the eruption, quickly detected by MODIS and OMI, traveled around the world (see papers in the Okmok-Kasatochi special issue of $J$. Geophys. Res.). The Bezymianny volcano $\left(55.98^{\circ} \mathrm{N}, 160.58^{\circ} \mathrm{E}\right)$ erupted at $1030 \mathrm{UTC} 19$ August 2008, producing an ash plume up to $9 \mathrm{~km}$ that drifted west $\sim 1200 \mathrm{~km}$ (data available from the Alaskan Volcano Observatory online at http://www.avo.alaska.edu). The plume of the former can be followed in the $\mathrm{OMI} \mathrm{SO}_{2}$ data from the time of the eruption until its arrival in the vicinity of Hokkaido 2 weeks later. The arrival of the Kasatochi plume, however, coincides well with the arrival of the plume of the latter as well. Thus, identifying which of the two plumes our sonde actually detected may be difficult.

Back trajectories at 500 and $1500 \mathrm{~m}$ for this case (not shown, but found online at physics.valpo.edu/ozone/ fulbrightdata.html) were calculated using the NASA Goddard Space Flight Center (GSFC) Trajectory Model (Schoeberl and Sparling 1995) run in kinematic mode (hereafter referred to as the KTM) with National Centers for Environmental Prediction (NCEP) reanalysis $\left(1^{\circ} \times 1^{\circ} \times 6 \mathrm{~h}\right)$ meteorological fields. The trajectories show the air masses over the previous 3 days arriving from the north-northeast, descending in altitude from $\sim 1.5$ to $0.5 \mathrm{~km}$ and from $\sim 4$ to $1.5 \mathrm{~km}$, respectively, as they passed over the Sea of Okhotsk into Hokkaido. KTM forward trajectories run from the time of the Kasatochi eruption through 22 August 2008 indicate 


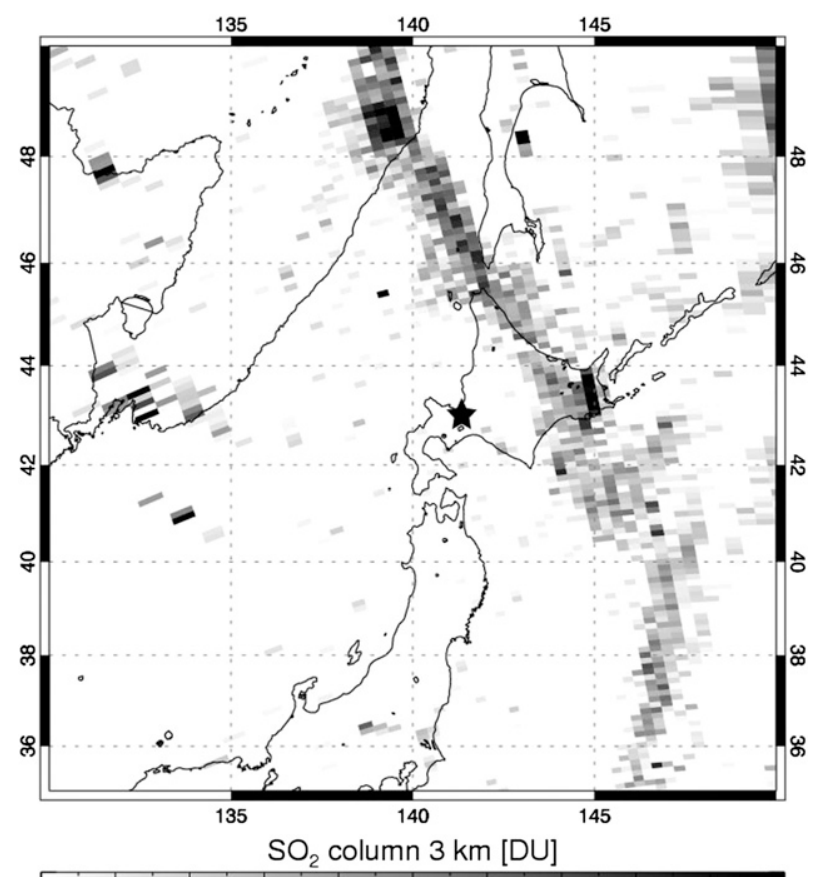

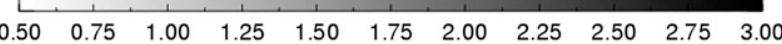

FIG. 11. OMI SO 2 retrieval assuming a $3-\mathrm{km}$ height for the arriving $\mathrm{SO}_{2}$ plume shows a 2.5+ DU cloud moving across Hokkaido on 22 Aug 2008. The position of Sapporo is marked by the star in the figure. The balloon flight was due south-southeast from Sapporo, parallel to the high- $\mathrm{SO}_{2}$ feature seen in the OMI data. See text for further details.

strong descent as the air mass arrived near Hokkaido (these trajectories can be found online at http://physics. valpo.edu/ozone/data/Fulbright/trajectory/kasatochi_ simulation/kasatochi_simulation.mov). Hybrid SingleParticle Lagrangian Integrated Trajectory (HYSPLIT) model (Draxler and Rolph 2010) trajectories for the Bezymianny eruption are shown in Fig. 12. The air parcel initialized at $\sim 5 \mathrm{~km}$ altitude arrives nearer to Sapporo than the Kasatochi plume seen in the $\mathrm{OMI} \mathrm{SO}_{2}$ data (Fig. 11).

Despite the theta profile that indicates that the peak was observed within the boundary layer, we believe this $\mathrm{SO}_{2}$ peak is not of local origin. In particular, we have looked at the dependence of the dual-sonde-measured $\left[\mathrm{SO}_{2}\right]$ in the lower $1.0 \mathrm{~km}$ for all of our balloon flights in August 2008 and August 2009 from Sapporo, excluding the 22 August 2008 case. We find that northwesterly, northerly, or northeasterly winds (as was the case for the 22 August 2008 profile) produced mean $\left[\mathrm{SO}_{2}\right]=1.11 \pm$ $0.66 \mathrm{ppbv}$. Easterly, southeasterly, and southerly winds, on the other hand, produced mean $\left[\mathrm{SO}_{2}\right]=1.8 \pm 1.2 \mathrm{ppbv}$. Although not statistically significant given the limited number of profiles and the typically low local $\mathrm{SO}_{2}$ concentrations, such differences can be explained by local geography, with the sea to the north providing cleaner air and the industrial centers to the southeast providing more polluted air. It seems likely, therefore, that the source of the $\mathrm{SO}_{2}$ peak is different than the usual urban centers southeast of Sapporo and may well be linked to one of the two volcanic eruptions (described above).

\section{c. Houston plume case}

The Study of Houston Atmospheric Radical Precursors (SHARP) campaign occurred from 15 April to 31 May 2009. As part of that campaign, 19 ozonesondes were released from the campus of the University of Houston $\left(29.72^{\circ} \mathrm{N}, 95.34^{\circ} \mathrm{W}\right.$; el.19 m). On two occasions, dual $\mathrm{O}_{3}-\mathrm{SO}_{2}$ sonde balloon payloads were flown to detect plumes emitted from industrial facilities in the Houston ship channel region (east of campus). It was found as part of this study that when light easterly winds were present, monitors on the UH Moody Tower frequently recorded higher levels of $\mathrm{SO}_{2}$.

Figure 13 shows the $\mathrm{O}_{3}, \mathrm{SO}_{2}, \mathrm{RH}$, and theta profiles for the dual sonde released at 1323 UTC (shortly after dawn) on Saturday, 30 May 2009. Ozone increased from $\sim 15 \mathrm{ppbv}$ at the surface to $80 \mathrm{ppbv}$ at $1.3 \mathrm{~km}$. $\mathrm{SO}_{2}$ increased from $\sim 11$ ppbv near the surface to $\sim 55$ ppbv near $400 \mathrm{~m}$. Winds near $400 \mathrm{~m}$ as reported by the sonde were light $\left(<4 \mathrm{~m} \mathrm{~s}^{-1}\right)$ and generally from the east-southeast direction. Moody Tower 1-min-average $\mathrm{SO}_{2}$ readings on this morning peaked at 38 ppbv at 1154 UTC, while the hourly average at the nearby Continuous Ambient Monitoring Station $81\left(29.73^{\circ} \mathrm{N}, 95.32^{\circ} \mathrm{W}\right)$ peaked at $1300-1400$ UTC at $12.4 \mathrm{ppbv}$ [data available online from the Texas Commission for Environmental Quality (TCEQ) at http:// www.tceq.state.tx.us].

Back trajectories were calculated at 250, 500, and 750 m with the UH Regional Data Assimilation System (UH-RDAS), with winds from the NCEP North America Mesoscale Model (NAM). The domain is interpolated to 12- and 4-km resolution, then adjusted by observations using the objective analysis module in the fifth-generation Pennsylvania State University-National Center for Atmospheric Research Mesoscale Model (MM5) (Grell et al. 1994). These trajectories suggest air arriving at UH from the east-northeast. HYSPLIT back trajectories, calculated at 300,400 , and $500 \mathrm{~m}$, suggest sources to the east or southeast of UH. (A map of the 300- and 400-m HYSPLIT trajectories and the 750-m UH-RDAS trajectory can be accessed online at http://www.imaqs.uh. edu/ozone/ourdata.html via a link in the 2009 data table in the row labeled "20090530, 13:23.") The trajectories suggest that influences from sites along the Houston Ship Channel are possible. Examining the upset inventory maintained by the TCEQ (available online at http://www. tceq.state.tx.us), we find that Houston Refining (12000 


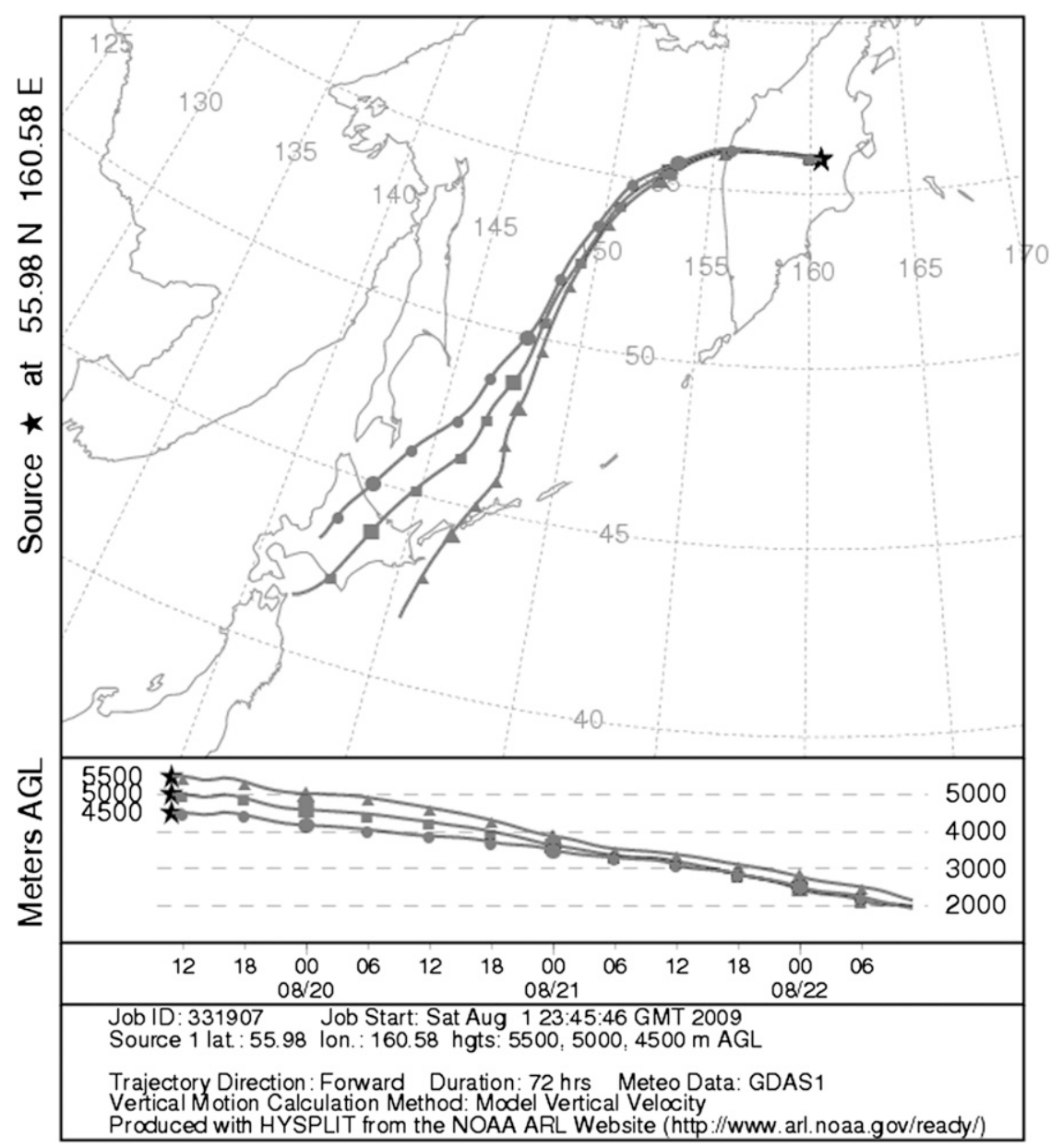

FIG. 12. HYSPLIT forward trajectories [graphical output described in Rolph (2010)] from Mt. Bezymianny on the Kamchatka Peninsula started at 1100 UTC 19 Aug 2008 at the time of an observed eruption. The trajectories descend rapidly and arrive near Sapporo at the time of the dual-sonde release (data shown in Fig. 10). See text for details.

Lawndale St., very near to the 300-m HYSPLIT back trajectory) reported the emission of $\sim 1900 \mathrm{~kg}$ of $\mathrm{SO}_{2}$ between 0200 and 0710 UTC 30 May 2009. Thus, the most likely explanation for this plume is a primary source at this industrial plant along the ship channel.

\section{Summary}

This work has presented a new technique for inexpensively measuring tropospheric $\mathrm{SO}_{2}$ plumes using a modified dual-ozonesonde approach. This technique is useful for validation of satellite $\mathrm{SO}_{2}$ observations as well as transport studies of $\mathrm{SO}_{2}$ plumes, both from natural (volcanic) and anthropogenic sources.

Laboratory tests found the EnSci $\mathrm{SO}_{2}$ filter made with $\mathrm{CrO}_{3}$ most effective at removing $\mathrm{SO}_{2}$ from the inlet airstream, with $\sim 100 \%$ removal by the new Teflon paper filters. These tests further showed that the filters did not interfere with measurements of $\mathrm{O}_{3}$ and demonstrated that the filters remained effective at removing $\mathrm{SO}_{2}$ even after exposure to $\sim 2.8 \times 10^{16}$ molecules.

By flying balloons with two ozonesondes on the same payload, one with an $\mathrm{SO}_{2}$ filter and one without, $\mathrm{O}_{3}$ and $\mathrm{SO}_{2}$ profiles can be measured simultaneously. Laboratory tests and field experience suggest that the detection limit is around $3 \mathrm{ppbv}$ for altitudes below the ozonopause (i.e., $<\sim 8-10 \mathrm{~km}$ ). Readings near and above the ozonopause probably are not robust, as the derived $\mathrm{SO}_{2}$ concentration becomes the difference between two relatively large numbers. Since reported ozonesonde measurement accuracy is $5 \%-10 \%$, when $\mathrm{O}_{3}$ concentrations reach 200 ppbv, these accuracy limitations can result in 10-20-ppbv $\mathrm{SO}_{2}$ readings at altitudes where no $\mathrm{SO}_{2}$ is present. Thus, we recommend our dual-sonde approach only for lower- to midtropospheric $\mathrm{SO}_{2}$ profiles. Care must be taken in deriving the $\mathrm{SO}_{2}$ profiles for 


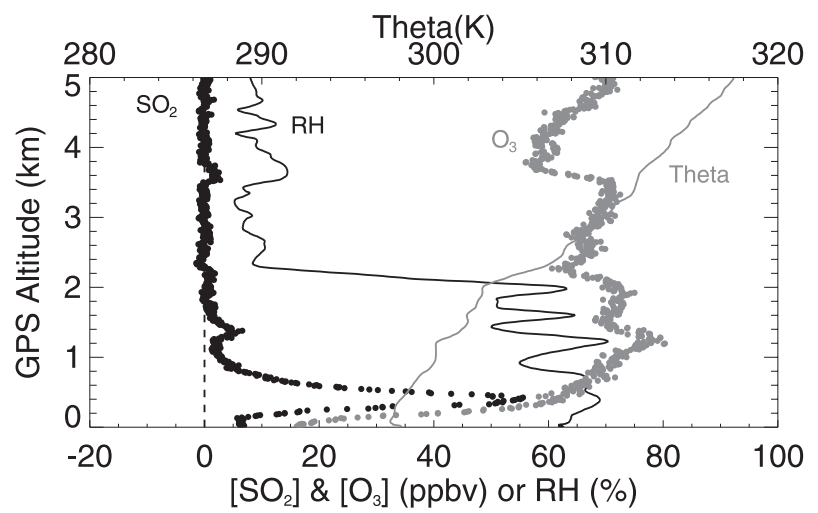

FIG. 13. As in Fig. 10, but for the dual-sonde from the University of Houston on 30 May 2009. A peak of $>60$ ppbv of $\mathrm{SO}_{2}$ was observed near $0.4 \mathrm{~km}$. See text for further details.

sondes with different time constants, particularly when the vertical $\mathrm{O}_{3}$ gradient is large.

Before flight the $\mathrm{SO}_{2}$ filters should be conditioned with $2-4 \mathrm{~h}$ of high $-\mathrm{O}_{3}$ air. Furthermore, it is important that the filter paper be dry before high- $\mathrm{O}_{3}$ conditioning. One hour of baking in an $80^{\circ} \mathrm{C}$ oven is sufficient to insure that the filter paper is dry.

Two examples demonstrated the effectiveness of the technique in measuring $\mathrm{SO}_{2}$ plumes. The 22 August 2008 flight from Sapporo, Japan, detected an $\mathrm{SO}_{2}$ plume near $700 \mathrm{~m}$ that most likely was emitted by a volcanic eruption. The 30 May 2009 flight from Houston, Texas, detected an $\mathrm{SO}_{2}$ plume near $400 \mathrm{~m}$ that most likely was emitted by industrial processes.

For ECC sonde operators near $\mathrm{SO}_{2}$ sources, it is recommended that $\mathrm{SO}_{2}$ filters be deployed on the inlet to remove $\mathrm{SO}_{2}$ and accurately retrieve $\mathrm{O}_{3}$. If possible, dual sondes as described here should be flown in such locations to provide the most reliable $\mathrm{O}_{3}$ profiles and simultaneous $\mathrm{SO}_{2}$ profiles. Before launching the dual-sonde payloads, we recommend reviewing local air traffic regulations and contacting local air safety officials.

Acknowledgments. Funding for this work was provided by NASA's Aura Validation Program (D. Considine and E. Hilsentrath, program managers) and by the JapanU.S. Educational Commission through a Fulbright Scholar grant. Thanks to the OMI team for the $\mathrm{SO}_{2}$ data and Hokkaido University and the Frontier Research Center for Global Change in Yokohama, Japan, for hosting the lead author of this study, with particular thanks to M. Fujiwara and F. Hasebe at Hokkaido University for assisting with the dual-sonde balloon flights from Sapporo, Japan, and to H. Akimoto for sponsoring my time in Japan. Special thanks also to the students at the University of Houston, in particular
M. Taylor, N. Grossberg, and C. Haman, who helped with dual-sonde balloon flights and/or preparation of laboratory equipment for the $\mathrm{SO}_{2}$ filter test at $\mathrm{UH}$ and to Winston Luke for loaning us the $\mathrm{SO}_{2}$ analyzer for the laboratory test. Thanks to B. Johnson (NOAA/Earth System Research Laboratory) for preparing the cathode and anode solutions used in this study, and thanks to Valparaiso University colleague Thomas Goyne and to the anonymous reviewers for their helpful comments for improving our manuscript. The authors gratefully acknowledge the NOAA/Air Resources Laboratory (ARL) for the provision of the HYSPLIT transport and dispersion model and/or the READY Web site (http:// www.arl.noaa.gov/ready.php) used in this publication.

\section{APPENDIX}

\section{ECC Filter Tests}

Many of the following tests employed the EnSci ozonizer unit to produce ozone and measure the current flowing between the cathode and anode cells, hereafter referred to as the intercell current (IC). The ozonizer consists of a UV lamp with an adjustable shield that produces ozone in a tube of air flowing next to the lamp. High ozone concentrations up to 4 ppmv can be achieved by turning off the ozonizer air pump, pulling the UV shield completely out, and drawing air past the UV lamp at the ozonesonde pump flow rate $\left(\sim 200 \mathrm{cc} \mathrm{min}^{-1}\right)$. Lower concentrations $(0-\sim 500 \mathrm{ppbv})$ are achieved by running the ozonizer air pump and adjusting the shield until the desired IC is achieved. Descriptions of the ozonizer unit and its operation can be found in Komhyr (1999).

\section{a. Empty cell and filter paper tests}

We assessed the impact of the various materials from which our $\mathrm{SO}_{2}$ filter is constructed. An ECC ozonesonde was run on ozone-free air for 5 min with a background cell current of $0.03 \mu \mathrm{A}$, then run with ozonated air with a resulting $\mathrm{IC}=\sim 5 \mu \mathrm{A}$ for $5 \mathrm{~min}$, with a final reading of $4.98 \mu \mathrm{A}$. An empty Teflon cell of the same type that is used to hold the cathode and anode solutions was inserted between the inlet side of the pump and a constant known $\mathrm{O}_{3}$ source. For an unconditioned cell, the IC dropped $>50 \%$, while for a high- $\mathrm{O}_{3}$-conditioned (i.e., $5 \mathrm{~h}$ of high $\mathrm{O}_{3}$ exposure) cell, the IC dropped $5 \%-12 \%$. The fact that the empty, conditioned Teflon cell itself results in $\mathrm{O}_{3}$ loss is interesting, as the ECC approach to measuring $\mathrm{O}_{3}$ profiles has been used worldwide and demonstrated to be accurate and reliable for more than $35 \mathrm{yr}$.

When measuring ozone with the ECC ozonesonde, the incoming air bubbles through the cathode solution. Reactions in the solution in the presence of the platinum 
electrode, therefore, must take place on a time scale smaller than the diffusion of air in the solution to the Teflon cell walls. With a pump flow rate of $\sim 200 \mathrm{cc} \mathrm{min}^{-1}$ and a Teflon cell volume of $\sim 5 \mathrm{cc}$, this puts an absolute upper limit of $\sim 1.5 \mathrm{~s}$ on the reaction time constant.

We next placed an unshredded, unconditioned, $1.3-\mathrm{cm}-$ diameter Teflon filter paper disk (the same size as the Teflon filter cell inner diameter) over the outlet port on the inside of the filter cell and inserted this filter between the inlet side of the pump and a constant known $\mathrm{O}_{3}$ source. The IC dropped by $40 \%$. This test was repeated using an unshredded, unconditioned, $2.0-\mathrm{cm}$ glass fiber paper, which when placed between the constant ozone source and the pump led to an IC drop of $60 \%$. It appears, therefore, that use of the Teflon filter paper is preferable to the glass fiber filter paper for construction of the $\mathrm{SO}_{2}$ filter.

Finally, we shredded one untreated, unconditioned, 3.7-cm Teflon filter paper disk into approximately eight pieces, folded the pieces in half, and placed them inside the Teflon filter cell. When this filter cell was inserted between the inlet side of the pump and a constant known $\mathrm{O}_{3}$ source, the IC dropped by $>80 \%$. The additional surface area provided by the shredded paper left a lot of surfaces for ozone deposition and destruction to take place.

\section{b. $\mathrm{H}_{2} \mathrm{O}$ version}

We examined the impact of water on the measurement of $\mathrm{SO}_{2}$ and $\mathrm{O}_{3}$. We conditioned a Teflon cell with high $\mathrm{O}_{3}$ for $30 \mathrm{~min}$, then ran for $10 \mathrm{~min}$ on $\mathrm{O}_{3}$-free air. Upon insertion of this Teflon cell between the outlet side of the pump and the cathode cell, the IC dropped $30 \%-40 \%$. Water was added slowly to the Teflon cell until it was about half full; the IC was observed not to change, whether the incoming air was bubbled through the $\mathrm{H}_{2} \mathrm{O}$ or cycled though the cell above the water level (i.e., sent through $100 \%$ relative humidity air).

We reran the test using a Teflon cell that had been high- $\mathrm{O}_{3}$ conditioned with dry air for $4 \mathrm{~h}$. As before, when inserted between the pump and the $\mathrm{O}_{3}$ source, the empty, conditioned Teflon cell resulted in an IC drop of $13 \%$. Water again was slowly added to the Teflon cell. This time, however, the IC dropped by $70 \%$ after about $1 \mathrm{~min}$, then slowly rose to a $\sim 24 \%$ deficit after $5 \mathrm{~min}$, with the recovery likely due to the increasing dissolved $\mathrm{O}_{3}$ content in the $\mathrm{H}_{2} \mathrm{O}$ slowing its further absorption as saturation was approached.

Measurements by the CIMS (described above) of air after passing through the $\mathrm{H}_{2} \mathrm{O}$ filter indicated nearcomplete destruction of $\mathrm{SO}_{2}$. When the $\mathrm{SO}_{2}$ air was passed through the $\mathrm{H}_{2} \mathrm{O}$ filter cell without bubbling through the $\mathrm{H}_{2} \mathrm{O}$, little to no $\mathrm{SO}_{2}$ was removed.

\section{c. Other filters}

We tested filters made from filter paper soaked in $\mathrm{NaHCO}_{3}$ and $\mathrm{KMnO}_{4}$ solutions, then dried. In the former case, the IC current dropped $50 \%$, suggesting an interference with the measurement of $\mathrm{O}_{3}$. In the latter case, IC current drops were $>12 \%$. Initially, the $\mathrm{KMnO}_{4}$ filter removed nearly $100 \%$ of incident $\mathrm{SO}_{2}$ (as indicated by tests using the apparatus in Fig. 7, described above), but 1 week after its construction, the filter no longer removed $\mathrm{SO}_{2}$. Thus, we were unable to create successfully a filter using $\mathrm{NaHCO}_{3}$ or $\mathrm{KMNnO}_{4}$.

\section{REFERENCES}

Benkovitz, C. M., S. E. Schwartz, M. P. Jensen, M. A. Miller, R. C. Easter, and T. S. Bates, 2004: Modeling atmospheric sulfur over the Northern Hemisphere during the Aerosol Characterization Experiment 2 experimental period. J. Geophys. Res., 109, D22207, doi:10.1029/2004JD004939.

Bovensmann, H., J. P. Burrows, M. Buchwitz, J. Frerick, S. Noël, V. V. Rozanov, K. V. Chance, and A. P. H. Goede, 1999: SCIAMACHY: Mission objectives and measurement modes. J. Atmos. Sci., 56, 127-150.

Bramstedt, K., A. Richter, M. Van Roozendael, and I. De Smedt, 2004: Comparisons of SCIAMACHY sulfur dioxide observations. Proc. Second Workshop on the Atmospheric Chemistry Validation of Envisat (ACVE-2), Frascati, Italy, European Space Agency, ESA SP-562. [Available online at http://envisat. esa.int/workshops/acve2/papers/ESC02KB.pdf.]

Burrows, J. P., and Coauthors, 1999: The Global Ozone Monitoring Experiment (GOME): Mission concept and first scientific results. J. Atmos. Sci., 56, 151-175.

Carn, S. A., A. J. Krueger, G. S. J. Bluth, S. J. Schaefer, N. A. Krotkov, I. M. Watson, and S. Datta, 2003: Volcanic eruption detection by the Total Ozone Mapping Spectrometer (TOMS) instruments: A 22-year record of sulfur dioxide and ash emissions. Volcanic Degassing, C. Oppenheimer, D. M. Pyle, and J. Barclay, Eds., Special Publication 213, Geological Society of London, 177-202. ,-- N. A. Krotkov, and M. A. Gray, 2004: Fire at Iraqi sulfur plant emits $\mathrm{SO}_{2}$ clouds detected by Earth Probe TOMS. Geophys. Res. Lett., 31, L19105, doi:10.1029/2004GL020719.

Chin, M., and Coauthors, 2000: Atmospheric sulfur cycle simulated in the global model GOCART: Comparison with field observations and regional budgets. J. Geophys. Res., 105 (D20), 24 689-24 712.

Dickerson, R. R., and Coauthors, 2007: Aircraft observations of dust and pollutants over northeast China: Insight into the meteorological mechanisms of transport. J. Geophys. Res., 112, D24S90, doi:10.1029/2007JD008999.

Draxler, R. R., and G. D. Rolph, cited 2010: HYSPLIT (HYbrid Single-Particle Lagrangian Integrated Trajectory) Model access via NOAA ARL READY Website. NOAA/Air Resources Laboratory, Silver Spring, MD. [Available online at http:// ready.arl.noaa.gov/HYSPLIT.php.]

Eisinger, M., and J. P. Burrows, 1998: Tropospheric sulfur dioxide observed by the ERS-2 GOME instrument. Geophys. Res. Lett., 25, 4177-4180.

EPA, 2000: National Air Pollutant Emission Trends, 1900-1998. U.S. Environmental Protection Agency, Office of Air Quality Planning and Standards Rep. EPA-454/R-00-002, 238 pp. 
[Available online at http://www.epa.gov/ttn/chief/trends/trends98/ trends98.pdf.]

Fioletov, V. E., E. Griffioen, J. B. Kerr, D. I. Wardle, and O. Uchino, 1998: Influence of volcanic sulfur dioxide on spectral UV irradiance as measured by Brewer spectrophotometers. Geophys. Res. Lett., 25, 1665-1668.

Galle, B., and Coauthors, 2010: Network for Observation of Volcanic and Atmospheric Change (NOVAC) - A global network for volcano gas monitoring: Network layout and instrument description. J. Geophys. Res., 115, D05304, doi:10.1029/ 2009JD011823.

Grell, G. A., J. Dudhia, and D. Stauffer, 1994: A description of the Fifth-Generation Penn State/NCAR Mesoscale Model (MM5). NCAR Tech. Note NCAR/TN-398+STR, 121 pp.

Hirokawa, J., T. Kato, and F. Mafuné, 2009: In situ measurements of atmospheric nitrous acid by chemical ionization mass spectrometry using chloride ion transfer reactions. Anal. Chem., 81, 8380-8386.

Huey, L. G., D. R. Hanson, and C. J. Howard, 1995: Reactions of $\mathrm{SF}_{6}^{-}$and $\mathrm{I}^{-}$with atmospheric trace gases. J. Phys. Chem., 99, 5001-5008.

Kearney, C. S., K. Dean, V. J. Realmuto, I. M. Watson, J. Dehn, and F. Prata, 2008: Observations of $\mathrm{SO}_{2}$ production and transport from Bezymianny volcano, Kamchatka using the MODerate resolution Infrared Spectroradiometer (MODIS) Int. J. Remote Sens., 29, 6647-6665.

Khokhar, M. F., C. Frankenberg, M. Van Roozendael, S. Beirle, S. Kühl, A. Richter, U. Platt, and T. Wagner, 2005: Satellite observations of atmospheric $\mathrm{SO}_{2}$ from volcanic eruptions during the time-period of 1996-2002. Adv. Space Res., 36, 879-887.

Kloster, S., and Coauthors, 2008: Influence of future air pollution mitigation strategies on total aerosol radiative forcing. Atmos. Chem. Phys., 8, 6405-6437.

Komhyr, W. D., 1969: Electrochemical concentration cells for gas analysis. Ann. Geophys., 25, 203-210.

_ 1986: Operations handbook: Ozone measurements to $40 \mathrm{~km}$ altitude with mode $4 \mathrm{~A}$ electrochemical concentration cell (ECC) ozonesondes (used with 1680-Mhz radiosondes). NOAA Tech. Memo. ERLARL-149, 49 pp.

_ 1999: En-Sci Corporation Model KTU-2A Ozonesonde Ozonizer/Test Unit, 7 pp. [Available from EnSci Corporation, P.O. Box 3234, Boulder, CO 80303.]

—_, R. A. Barnes, G. B. Brothers, J. A. Lathrop, and D. P. Opperman, 1995: Electrochemical concentration cell performance evaluation during STOIC. J. Geophys. Res., 100, 9231-9244.

Krotkov, N. A., A. J. Krueger, and P. K. Bhartia, 1997: Ultraviolet optical model of volcanic clouds for remote sensing of ash and sulfur dioxide. J. Geophys. Res., 102 (D18), 21 891-21 904.

_ , S. A. Carn, A. J. Krueger, P. K. Bhartia, and K. Yang, 2006: Band residual difference algorithm for retrieval of SO2 from the aura Ozone Monitoring Instrument (OMI). IEEE Trans. Geosci. Remote Sens., 44, 1259-1266.

_ , K. Yang, A. Krueger, S. A. Carn, P. K. Bhartia, and P. F. Levelt, 2007: $\mathrm{SO}_{2}$ data from the Ozone Monitoring Instrument. Proc. ENVISAT Symp. 2007, Montreux, Switzerland, European Space Agency, ESA SP-636, 509823. [Available online at http://envisat.esa.int/envisatsymposium/proceedings/sessions/ 3G2/509823kr.pdf.]

- - and Coauthors, 2008: Validation of $\mathrm{SO}_{2}$ retrievals from the Ozone Monitoring Instrument over NE China. J. Geophys. Res., 113, D16S40, doi:10.1029/2007JD008818.
Krueger, A. J., 1983: Sighting of El Chichon sulfur dioxide with the Nimbus-7 total ozone mapping spectrometer. Science, 220, 1377-1378.

— L. S. Walter, P. K. Bhartia, C. C. Schnetzler, N. A. Krotkov, I. Sprod, and G. J. S. Bluth, 1995: Volcanic sulfur-dioxide measurements from the total ozone mapping spectrometer instruments. J. Geophys. Res., 100 (D7), 14 057-14 076.

, S. J. Schaefer, N. Krotkov, G. Bluth, and S. Barker, 2000: Ultraviolet remote sensing of volcanic emissions. Remote Sensing of Active Volcanism, Geophys. Monogr., Vol. 116, Amer. Geophys. Union, 25-43.

Lee, C., A. Richter, M. Weber, and J. P. Burrows, 2008: $\mathrm{SO}_{2}$ retrieval from SCIAMACHY using the Weighting Function DOAS (WFDOAS) technique: Comparison with standard DOAS retrieval. Atmos. Chem. Phys., 8, 6137-6145.

- R. V. Martin, A. Donkelaar, G. O'Byrne, N. A. Krotkov, A. Richter, L. G. Huey, and J. S. Holloway, 2009: Retrieval of vertical columns of sulfur dioxide from SCIAMACHY and OMI: Air mass factor algorithm development, validation, and error analysis. J. Geophys. Res., 114, D22303, doi:10.1029/ 2009JD012123.

Levelt, P. F., E. Hilsenrath, G. W. Leppelmeier, G. B. J. van den Oord, P. K. Bhartia, J. Tamminen, J. F. de Haan, and J. P. Veefkind, 2006a: Science objectives of the Ozone Monitoring Instrument. IEEE Trans. Geosci. Remote Sens., 44, 1199-1208.

— , and Coauthors, 2006b: The Ozone Monitoring Instrument. IEEE Trans. Geosci. Remote Sens., 44, 1093-1101.

Lovejoy, E. R., and R. R. Wilson, 1998: Kinetic studies of negative ion reactions in a quadrupole ion trap: Absolute rate coefficients and ion energies. J. Phys. Chem. A, 102, 2309-2315.

Luke, W. T., 1997: Evaluation of a commercial pulsed fluorescence detector for the measurement of low-level $\mathrm{SO}_{2}$ concentrations during the Gas-Phase Sulfur Intercomparison Experiment. J. Geophys. Res., 102, 16 255-16 265.

Richter, A., F. Wittrock, and J. P. Burrows, 2006: $\mathrm{SO}_{2}$ measurements with SCIAMACHY. Proc. Atmospheric Science Conf., Frascati, Italy, European Space Agency, ESA SP-628, 6 pp. [Available online at http://earth.esa.int/workshops/atmos2006/ participants/804/paper_richter_esa_06.pdf.]

Rolph, G. D., cited 2010: Real-time Environmental Applications and Display sYstem (READY). NOAA/Air Resources Laboratory, Silver Spring, MD. [Available online at http://ready.arl.noaa.gov/.]

Saltzman, B. E., and A. F. Wartburg, 1965: Absorption tube for removal of interfering sulfur dioxide in analysis of atmospheric oxidant. Anal. Chem., 37, 779-782.

Schoeberl, M. R., and Coauthors, 2006: Overview of the EOS Aura Mission. IEEE Trans. Geosci. Remote Sens., 44, 1066-1074. , and L. Sparling, 1995: Trajectory Modeling, in Diagnostic Tools in Atmospheric Physics. Proc. Int. Sch. Phys. "Enrico Fermi,"' 124, 289-306.

Seinfeld, J. H., and S. N. Pandis, 1998: Atmospheric Chemistry and Physics: From Air Pollution to Climate Change. John Wiley and Sons, $1326 \mathrm{pp}$.

Smit, H. G., and Coauthors, 2007: Assessment of the performance of ECC-ozonesondes under quasi-flight conditions in the environmental simulation chamber: Insights from the Jülich Ozone Sonde Intercomparison Experiment (JOSIE). J. Geophys. Res., 112, D19306, doi:10.1029/2006JD007308.

Soloman, S., D. Qin, M. Manning, Z. Chen, M. Marquis, K. B. Averyt, M. Tignor, and H. L. Miller, Eds., 2007: Climate Change 2007: The Physical Science Basis. Cambridge University Press, 996 pp.

Taubman, B. F., J. C. Hains, A. M. Thompson, L. T. Marufu, B. G. Doddridge, J. W. Stehr, C. A. Piety, and R. R. Dickerson, 
2006: Aircraft vertical profiles of trace gas and aerosol pollution over the mid-Atlantic United States: Statistics and meteorological cluster analysis. J. Geophys. Res., 111, D10S07, doi:10.1029/ 2005JD006196.

Thomas, W., T. Erbertseder, T. Ruppert, M. van Roozendael, J. Verdebout, D. Balis, C. Meleti, and C. Zerefos, 2005: On the retrieval of volcanic sulfur dioxide emissions from GOME backscatter measurements. J. Atmos. Chem., 50, 295-320.

Thompson, A. M., and Coauthors, 2003: Southern Hemisphere Additional Ozonesondes (SHADOZ) 1998-2000 tropical ozone climatology 1. Comparison with Total Ozone Mapping Spectrometer (TOMS) and ground-based measurements. J. Geophys. Res., 108, 8238, doi:10.1029/2001JD000967.

, and Coauthors, 2007: IONS (INTEX Ozonesonde Network Study, 2004). 1. Summertime UT/LS (upper troposphere/ lower stratosphere) ozone over northeastern North America. J. Geophys. Res., 112, D12S12, doi:10.1029/2006JD007441.
Warmbt, W., and G. Herrmann, 1977: Surface ozone measurements utilizing chromium trioxide filters. Proc. Joint Symposium Atmospheric Ozone, Vol. 1, Dresden, Germany, 179-188.

Yang, K., N. A. Krotkov, A. J. Krueger, S. A. Carn, P. K. Bhartia, and P. F. Levelt, 2007: Retrieval of large volcanic $\mathrm{SO}_{2}$ columns from the Aura Ozone Monitoring Instrument (OMI): Comparison and limitations. J. Geophys. Res., 112, D24S43, doi:10.1029/2007JD008825.

$\longrightarrow,-,-,-,-$, and,- 2009a: Improving retrieval of volcanic sulfur dioxide from backscattered UV satellite observations. Geophys. Res. Lett., 36, L03102, doi:10.1029/ 2008 GL036036.

—_, X. Liu, N. A. Krotkov, A. J. Krueger, and S. A. Carn, 2009b: Estimating the altitude of volcanic sulfur dioxide plumes from space borne hyper-spectral UV measurements. Geophys. Res. Lett., 36, L10803, doi:10.1029/ 2009GL038025. 
Copyright of Journal of Atmospheric \& Oceanic Technology is the property of American Meteorological Society and its content may not be copied or emailed to multiple sites or posted to a listserv without the copyright holder's express written permission. However, users may print, download, or email articles for individual use. 